\title{
NEW PLAYMAKER IN SCIENCE EDUCATION: COVID-19
}

\author{
Muhammet Usak, Alfiya R. Masalimova \\ Kazan (Volga region) Federal University, Russia \\ Elena I. Cherdymova \\ Samara University, Russia \\ Albina R. Shaidullina \\ Almetyevsk State Oil Institute, Russia
}

Nowadays, we all are sitting in our homes and watching what is going on in the world, as if we are watching a science fiction movie, in which we have the leading role. Novel Coronavirus (COVID-19), which first appeared in Wuhan (Abdulamir, \& Hafidh, 2020; Ait Addi et al., 2020 Aljofan, \& Gaipov, 2020; Sorooshian, 2020) and later turned into a pandemic affecting the entire world, does not discriminate between the degree of democracy, finances, religion, gender, ethnicity and region. World is a fireplace and we all are "burning".

In the countries where the pandemic is progressing rapidly, all health professionals, regardless of their area of expertise, have been called to the field. This reminds us of the need to revive the general perspective that we have begun to forget. That is to say, no matter how specific our area of expertise is, we are obliged to keep the general perspective of our field and basic doctrines constantly fresh.

The most important subject to teach our youth is that this world does not just belong to us alone. Unless we learn to live in harmony and respect with other living creatures who are sharing the nature with us, eventually it will remind us. As it is stated in a movie, right now, independent of race, religions and languages, we are but one klan: The Human Klan! And our klan is in danger.

When we look at what is currently happening from this perspective, it becomes evident that we all have to review ourselves, our fields of work, and our point of view. Longlasting science and biology education will also have its share from this settlement. Hereupon, closer relationship will be established between fields such as health, medicine, biology, psychology.

In this context, we intended to evaluate the emotions of deep anxiety and hopelessness in processes that are difficult to control, such as pandemics.

The problem of studying fear, as the most important modus operandi of human existence, as the basic instinct and mechanism of organization of an individual's inner world, has worried the minds of scientists of various disciplines since ancient times (Abakumova, 2003; Gobbs, 1964; Makarova et al., 2019; Omarova et al., 2018). The study of the general problem of fear has become widespread in various sciences (Astapov, 2001; Vitkovskaya, 2003, Čepulènas, Bobrova, \& Grajauskas, 2009; Romanovska et al., 2019). According to some researchers, the feeling of fear is the basis of the natural protective mechanism of the individual (Bąk et al., 2019; Orekhovskaya et al., 2019). Additionally, it is closely related to excitement, anxiety, alarm, fear, fright and terror (Akopyan, 2009; Torkar, 2015; Tomazic, Pihler, \& Strgar, 2017).

Fear of the future arises from the past and the present and is a reflection of what is accumulated to the present. Based on collective experience, one perceives and translates fears. In this case, it is legitimate to 
consider disaster consciousness as fear of future potential and real threats. Fears are inherent in every person, regardless of gender, age, social status or financial situation. It should be noted that pregnant women are no exception. However, pregnancy is a significant and important condition of a woman. During this period a new life is born, and a woman cares not only about herself, but also about the future child. There is a restructuring of the body both on the physical and on biological level, and as well as on psychological.

The study of the mother's influence on the health and mental integrity of the child is not new in psychology (Borovikova, 1998; Dolto, 1997; Raigorodsky, 2003). Many researchers emphasize the importance of early communication between mother and child. Modern researchers of pregnancy psychology have set themselves the task of studying factors that affect: the development of the child and the welfare of the mother - child dyad, the emotional state of pregnant women, their changes in the perception of the world, their attitude to the future child, and the impact of relationships with people during pregnancy (Belogai, 2004; Kovalenko, 1998; Loseva \& Lunkov, 2003; Misyuk \& Kovalenko, 2008).

In recent years, such aspects of motherhood as the emotional state of a woman during pregnancy, the factors and conditions of deviations in motherhood, and the personal changes of women associated with the transition to parenthood have been the subject of study (Goebel \& Gleclar, 1998; Izard, 2002; Khorni, 2008; Ushakova, 2014; Vasilyeva, 1999). Moreover, there is an active search for models of psychological support of a woman during pregnancy and during the first years of her life in science and practice. However, to date, the problem of socio-psychological fears of pregnant women remains poorly understood.

The purpose of this study is to analyze the peculiarities of socio-psychological fears of young female students and expectant mothers under the conditions of Coronavirus pandemic. On one hand, mass social fears are the result of modern society's functioning. On the other hand, fears arise in the process of adaptation to environmental changes and -to some extent- mobilize opposition to overcome the dangers and threats to the existence of individuals and groups.

Based on the specifics of the object and subject of the study, interview method was chosen as the method of empirical research to allow an effective analysis of the socio-psychological fears of pregnant women in a Coronavirus pandemic. The following main questions have been formulated to achieve the research objectives: 1) What socio-psychological fears do female students - future mothers have? 2) Which social and psychological fears prevail in the conditions of the Coronavirus pandemic? 3) What social-psychological fears have emerged with the beginning of pregnancy? 4) Has the number and strength of socio-psychological fears increased or decreased in the Coronavirus Pandemic conditions, depending on the duration of pregnancy?

Preparatory Stage: During the preparatory stage, the program of qualitative research was developed: the goal, object, subject of research and research questions were formulated; the research method was chosen; the sample was formed; the research tool - interview guide was developed.

Questions of the interview guide can be divided into nine categories:

1. questions to establish contact with the informants, find out general information about the term of pregnancy, whether its the first pregnancy or not, and the general well-being of the informants,

2. questions to identify the existence of fears with the informants and to identify the predominant fears with female students - future mothers in the Coronavirus pandemic conditions,

3. questions to identify fears of body changes and fear of childbirth,

4. questions to reveal fears concerning changes in material well-being,

5. questions to identify fears regarding the career and official position of informants,

6. questions to identify fears regarding changes in family life with a childbirth,

7. questions to identify fears regarding changes in social status and lifestyle after the birth of a child,

8. questions to identify fears about the child's future, his/her life,

9. questions to identify fears arising from pregnancy, as well as to identify the dynamics of fears in a Coronavirus pandemic condition, depending on the period of pregnancy of the informants.

Pilot Study Stage: After the preparatory stage was completed, first interview was executed as a pilot study. During this first interview, a number of problems arose:

1. Topic of the interview turned out to be more complex psychologically and emotionally than we had initially expected. In everyday life, few people think about their fears and underlying reasons. Additionally, it is difficult for informants to answer questions about existing and prevailing fears of interviews. Interview guide implies a conversation with informants on certain conditional parts 
disclosing certain types of social and psychological fears. In a situation where the informant has not thought about these fears independently before, there is a threat of negative psychological influence from the informant. In other words, if the informant initially names a small number of his/her fears, then during the interview he/she seriously reflects on the problems of socio-psychological fears discussed in the interview.

2. It is necessary to take into account the general psycho-emotional state of pregnant women participating in the study. Everyone perceives their pregnancy and the future of their child differently. Therefore, in order to avoid the effect of imposing new socio-psychological fears that the informant had not previously thought about, it is necessary to be very cautious in the formulation of the questions of the interview guide.

3. Some women prefer not to discuss these issues with outsiders. When addressing the state of pregnancy itself, the future of the child and possible changes in the life of the informant after childbirth, it is necessary to condider the degree of openness to discuss these issues when selecting informants.

Adjustment Stage: During this stage, we took into account all the problems and deficiencies identified during the pilot interview and made several adjustments to be applied during the rest of the study.

1. We revised the research sample to make a more careful selection of participants. Finding informants willing to openly and thoroughly discuss their fears, pregnancy, future of themselves and their child, is a challenging task. The psycho-emotional state of pregnant women was also taken into account. Informants who are sensitive and reverently protective of information about their pregnancy and all matters directly or indirectly related to it were excluded from the research sample. Additionally, informants experiencing problems with the course of pregnancy were also excluded.

2. Necessity of a preliminary interview immediately before and after the actual interview was identified. Informal conversations before the actual interview tend to create a positive mood in informants by establishing closer contact with them. Further informal conversations after the actual interview tend to smooth out possible negative psycho-emotional effects. These pre- and post- informal conversation are shaped around simple and pleasant topics such as the term of pregnancy, sex and name of the child, and whether it is the first pregnancy or not.

Data Collection Stage: As part of the empirical study, 15 interviews in a free manner were conducted. Out of these 15 participants, 13 of them were expecting their first child. One participant was expecting her second child. Five participants were in their first trimester, five participants were in their second trimester and five participants were in their last trimester. The interviews were conducted according to a soft scheme, where the guide's questions were not filled in a strict sequence. Then all the interviews were transcribed for further analysis.

To the question "As you know, pregnant women become more sensitive, have you noticed this on yourself?", all 15 participants answered in the affirmative. $85 \%$ of participants noted that before pregnancy, they would not agree with this statement.

To the question on how they tolerated pregnancy, $65 \%$ of the participants assess their condition as satisfactory. Negative assessments of pregnancy's course were also presented for $20 \%$ of those surveyed. The remaining $15 \%$ described their pregnancy course as good.

To some extent, fears related to pregnancy are present in all informants. But, it should be noted that there are significant differences in perception and assessment of fears. Thus, the answers to the question: "Do you have any fears related to pregnancy?" are distributed approximately in equal proportions: some informants clearly say that there are fears (55\%), while another part of respondents prefer to talk not about fears, but about feelings, expectations on fears (45\%).

Among participants, the fear associated with the health of the child and the fear of childbirth are the most prevalent.

With regard to the fear for the health of the child, the following types of fear can be identified among the informants' answers: possible abnormalities in the development of the fetus (60\%); threats to the health of the child due to medical error and incompetence of doctors (15\%) and fear of Coronavirus (75\%), as female students and expectant mothers consider pregnant women more vulnerable (along with the elderly) to this virus. 
Regarding fear of childbirth, the informants' answers can be conventionally divided into two groups: in the first case, women spoke about fear of physical pain during childbirth (35\%); in the second case, the informants spoke about fear of possible complications during childbirth (20\%).

To the question on how they feel about the changes that are currently happening to their body, the answers of informants are divided into two opposite groups: women who treat these changes either mainly calmly $(75 \%)$, because they are considered inevitable and natural, or worried about changes in their bodies (15\%).

When considering the fear of a change in the financial situation after the birth of a child, it was found that informants considered this fact as an inevitable financial difficulty. When considering whether the informants had fear about their careers, it was found that there was a lack of fear, as well as a correlation to the value of children in life, as well as issues related to the deterioration of their financial situation.

To the question on how they feel about possible changes in family life after the birth of the child, most of the the informants have no these fears, since the birth of a child is considered not as a possible difficulty or obstacle, but as an important event in family life, as happiness (85\%). It should also be noted that some informants treat this issue quite calmly; possible changes in family life do not cause any special fears and experiences. Informants for whom the current pregnancy is not the first one have no fears and worries about this issue, and they note that no changes will occur.

To the question on whether they have any concerns about the child's health in the Coronavirus pandemic condition, it was concluded that all informants have increased level of fears about this issue.

Analysis Stage: To the best of our knowledge, this study is one of the first that concentrates on the sociopsychological fears of young female students and expectant mothers. It reveals that they experience fear of childbirth; fear associated with the health of the child; fear associated with novel Coronavirus pandemic; fear associated with the future of the child; fear of changes in lifestyle after birth; fear of difficulties in raising a child; fear of changes in the body after birth. Among these, three fears predominate among pregnant women: fear of childbirth, fear related to the health of the child, fear for the future of the child. These fears are inherent for all participants, regardless of the length of pregnancy and whether the current pregnancy is the first or second. It is determined that with the beginning of pregnancy, most of the female students surveyed who were going to be mothers, their social and psychological fears increased.

The study reveals that the fear for the future of the child is the most extensive in the interpretation of participants and includes such factors as a complex epidemiological situation associated with the Coronavirus pandemic; economic and political situation in the country and in the world; deterioration of the quality of education and medicine. For the first time, in conditions of the Coronavirus pandemic, it is revealed that most young mothers reported significant fear associated with the disease, and this fear ranks third in the social-psychological fear rankings of this sample.

Furthermore, it is determined that the emotion power of the Coronavirus pandemic fear is increased by such phenomena as: massovization and stereotyping of thinking and behavior of individuals. It has been shown that pregnant women are highly susceptible to the fear to be infected with Coronavirus.

To sum up, social-psychological fears are increasing in the sphere of scientists' interests. In modern society, with the help of mass media, everyone receives information that has taken place in the world. Often the information has a negative connotation. The spheres of threat deployment, risk indicators and their reflection in mass consciousness are considered. All this contributes to the formation and development of a disaster consciousness, especially in emotional people, including pregnant women. During pregnancy, as a special physical, psychological and social condition, women may exhibit largely certain socio-psychological fears that did not exist or were not prevalent before pregnancy. For a modern study of this phenomenon in the conditions of a Coronavirus pandemic, it is necessary to analyze in detail the peculiarities of constructing social and psychological fears of women during pregnancy.

\section{Acknowledgments}

The work is supported by the Russian Government Program of Competitive Growth of Kazan Federal University. 


\section{References}

Abakumova, T. V. (2003) Filosofskie aspekty fenomena straha [Philosophical aspects of fear phenomenon]. Abstract of the PhD. Yakutsk

Abdulamir, A. S., \& Hafidh, R. R. (2020). The possible immunological pathways for the variable immunopathogenesis of COVID-19 infections among healthy adults, elderly and children. Electronic Journal of General Medicine, 17(4), em202. https://doi.org/10.29333/ejgm/7850

Ait Addi, R., Benksim, A., Amine, M., \& Cherkaoui, M. (2020). Asymptomatic COVID-19 Infection Management: The Key to Stop COVID-19. Journal of Clinical and Experimental Investigations, 11(3), em00737. https://doi.org/10.5799/jcei/7866

Akopyan, L.S. (2009). Novyi podhod k klassificatcii strachov [New approach to the classification of fears]. News of Samara Scientific Center of the Russian Academy of Sciences, 4, 1472-1475.

Aljofan, M., \& Gaipov, A. (2020). Chloroquine and COVID-19: A light at the end of the tunnel, or is it another train? Electronic Journal of General Medicine, 17(4), em207. https://doi.org/10.29333/ejgm/7863

Astapov, V. M. (2001). Funktcionalnui podhod k izucheniu coctoiania trevogi. Trevoga I trevoznoct Hrestomatia.SP.b: Piter, 156$166 \mathrm{c}$. [Functional approach to studying the state of alarm]. Alarm and anxiety. Peter.

Bąk, T., Kardis, M., Valco, M., Kalimullin, A. M., \& Galushkin, A. A (2019). A philosophical-sociological diagnosis of youth subcultures in the context of social changes. XLinguae, 12(2), 163-185.

Čepulènas, A., Bobrova, L., \& Grajauskas, L. (2009). Students' psychosocial needs: Fulfilment and methodological background of their formation. Problems of Education in the 21st Century, 10, 156-170. http://www.scientiasocialis.It/pec/node/ files/pdf/Cepulenas.Vol.10.pdf

Belogai, K. N. (2004). Sovremennyje podhody k psihologicheskomu issledovaniju beremennosti [Modern approaches to the psychological study of pregnancy]. Materials of the scientific-practical conference. Russian State University.

Borovikova, N. V. (1998). Akmeologicheskii potentcial beremennoi zenshiny [Acmeological potential of a pregnant woman]. Socio-psychological analysis. Socinnovatsiya Publishing House.

Dolto, F. (1997). On the child side. XXI century.

Goebel, V., \& Gleclar, M. (1998). Child. From infancy to adulthood. Enigma publishing house.

Izard, C. E. (2002). Psihologia emotcii [Psychology of emotions]. Peter.

Khorni, K. (2008). Trevoga I trevoznost [Alert and anxiety]. PER SE.

Kovalenko, N. P. (1998). Psihologicheckie osobennosti l korrektcia emotcionalnogo sostoiania zenshiny v period beremennosti I rodov [Psychological features and correction of the emotional state of a woman during pregnancy and childbirth: Abstract of the PhD thesis]. St.Petersburg.

Loseva, V., \& Lunkov, A. (2003). Strahi vokrug beremennosti [Fears about pregnancy]. BAHRAM-M Publishing House.

Makarova, E. V., Kryukova, N. I., Sizova, Z. M., Grinenko, A. V., Erofeeva, M. A., \& Bukalerova, L. A. (2019). Divergence of supreme values of Russian world and western civilization social and philosophical analysis. European Journal of Science and Theology, 15(3), 97-107.

Misyuk, M. N., \& Kovalenko, E. S. (2008). Trevoznost I ctrahi kak proiavlenie emotcionalnoi cfery beremennyh zenshin. [Anxiety and fears as a manifestation of the emotional sphere of pregnant women]. Management in social and economic systems: m-Is of XVII International Scientific-Practical Conference (June 2-6, 2008, Minsk). Minsk In-t of Management.

Omarova, L. B., Kalimullin, A. M., Grudtsina, L. Y., Korzhuev, A. V., Zhukova, M. Y. (2018). Philosophical anthropology in postmodernism. XLinguae, 11(3), 76-85.

Orekhovskaya, N. A., Chistyakov, A. A., Kryukova, N. I., Krokhina, J. A., Ospennikov, Y. V., \& Makarova, E. V. (2019). Orthodoxy and modernity their contact facets in Russian society. European Journal of Science and Theology, 15(2), 67-77.

Potyrała, K. (2020) A few reflections on contemporary science education and educational research. Problems of Education in the 21st Century, 78(1), 4-8. https://dx.doi.org/10.33225/pec/20.78.04

Raigorodsky, D. Ya. (2003). Psihologia I psihoanaliz beremennosti [Psychology and psychoanalysis of pregnancy]. BakhrakhMoscow Publishing House.

Romanovska, L., Horishna, N., Slozanska, H., \& Soroka, O. (2019). Exploring the leadership skills of pre-service social work students: Implications for social work education. Problems of Education in the 21st Century, 77(5), 598-615. https:// dx.doi.org/10.33225/pec/19.77.598

Sorooshian, S. (2020). Quarantine decision due to coronavirus pandemic. Electronic Journal of General Medicine, 17(4), em206. https://doi.org/10.29333/ejgm/7862

Torkar, G. (2015). Pre-service teachers' fear of snakes, conservation attitudes, and likelihood of incorporating animals into the future science curriculum. Journal of Baltic Science Education, 14(3), 401-410.

Tomažič, l., Pihler, N., \& Strgar, J. (2017). Pre-service biology teachers'reported fear and disgust of animals and their willingness to incorporate live animals into their teaching through study years. Journal of Baltic Science Education, 16(3), 337-349.

Ushakova, V. R. (2014). Psihologicheckie osobennocti supruzeckih otnoshenii u zenshin s razlichnym techeniem beremennosti [Psychological characteristics of spousal relations among women with different phases of pregnancy]. Clinical and Medical Psychology: Research, Training, Practice: Electronic Scientific Journal, 2(4) 45-48.

Vasilyeva, O. S. (1999). Sotcialno-psihologicheskie aspekty perinatalnoi psihologii I psihologii beremennosti. [Socialpsychological aspects of perinatal psychology and the psychology of pregnancy]. Psychological Bulletin of Russian State University, 4, 176-181. 
Vitkovskaya, M. I. (2003). Teoretiko-metodicheskie problem izuchenia ctracha v cotciologii. [Theoretical and methodical problems of studying fear in sociology]. PFUR Bulletin. Sociology ser, 4(5), 74-79.

Muhammet Usak

(Corresponding author)

Alfiya R. Masalimova

Elena I. Cherdymova

Albina R. Shaidullina
PhD in Science Education, Associate Professor, Leading Research Fellow at Scientific and Educational Center of Pedagogical Researches, Kazan (Volga region) Federal University, Kazan, Russian Federation.

E-mail: musaktr@gmail.com ORCID ID: https://orcid.org/0000-0002-6537-9993

Doctor of Education, Professor, Head of the Department of Higher School Pedagogy of the Institute of Psychology and Education, Kazan (Volga region) Federal University, Kazan, Russian Federation.

E-mail: alfkazan@mail.ru ORCID ID: https://orcid.org/0000-0003-3711-2527

PhD in Psychology, Associate Professor of the Department of Sociology and Cultural Science, Samara National Research University named after Academician S.P. Korolev (Samara University), Samara, Russian Federation.

E-mail:cheiv77@mail.ru ORCID ID: https://orcid.org/0000-0002-0392-8483

Doctor of Education, Professor, Head of the Department of Foreign Languages, Almetyevsk State Oil Institute, Almetyevsk, Russian Federation.

E-mail: albina-plus@mail.ru ORCID ID: https://orcid.org/0000-0002-0648-4312 